\title{
RAPAT KOORDINASI DESA
}

\author{
GUNAWAN \\ 9173770410151 \\ sg9807473@gmail.com
}

\section{Bentuk Kegiatan}

Rapat koordinasi desa
Untuk mengetahui keadaan masingmasing posko peserta KKLP

\section{Lokasi}

Aula kampus STIE STKIP YAPTI JENEPONTO

3. Hari/Tanggal dan Waktu

Jumat, 18-09-2020, 11:00 - 11:58

\section{Peserta yang Dilibatkan}

- Panitia KKLP

- Koordinasi Kecamatan

- Koordinasi Desa

- Sekretaris

- Bendahara

- Anggota

\section{Tujuan dan Manfaat} Untuk mengetahui keadaan masingmasing posko peserta KKLP dan melakukan sharing bersama peserta KKLP.

\section{Deskripsi Kegiatan}

Rapat di mulai dari jam 11 sampai 11:58. Kegiatan ini dilakukan untuk mengetahui keadaan posko di setiap desa dan pemberian nasehat oleh ketua panitia.

\section{Alasan Diadakannya}

\section{Referensi Wajib}

- HERIANTO, H., \& Amir, A. S. (2020, September 10). Pedoman Pelaksanaan Kuliah Kerja Lapangan Plus (KKLP) Mahasiswa STIE dan STKIP YAPTI Jeneponto. https://doi.org/10.31219/osf.io/7dvpk 